\title{
Chinese Cultural Factors Favouring Biotechnology Research
}

\author{
James Miller \\ Queen's University
}

\section{Abstract}

This paper summarizes recent European research on social and cultural perceptions of biotechnology research, with a focus on transgenic mice. Secondly it attempts to consider some of the same questions from a Chinese cultural perspective.

\section{Keywords}

biotechnology research, Chinese culture, transgenic mice, religion, modernity

\section{Introduction: The Context of Modernity}

Any discussion of cultural arguments regarding religion, nature and biotechnology in the modern period must begin with the broad context of the worldview of Western modernity. Of course this is a highly charged and changing worldview, one that has itself been subject to change and transformation over four centuries of history. Despite this obvious caveat, it is possible and, more importantly, interesting to delineate the broad parameters within which modernity as a Problematik operated insofar as they are relevant to understanding the way in nature and technology function as constested sites in contemporary culture. To do so it is helpful to refer to two features of the worldview of modernity as described by Bronislaw Szerszynski (2005) in his recent book Nature, Technology and the Sacred.

The first is that in the modern period, nature came to be viewed as a unity. This is the result of what he terms the "long arc of monotheism" whereby divinity came to be expelled from the natural world (in the form of ghosts and spirits), and came instead to be construed as a divine law- 
maker whose absolute transcendent singularity guaranteed the universal applicability of the laws of nature. This theological transformation was condition for the possibility of construing nature as a universe held together by a single unbreakable thread of natural law (2005: 16-23).

The second salient feature he describes as constitutive of the modern view of nature is a process in which episteme (contemplation), or the rational knowledge of the laws of nature, became subordinated to techne, (craft), or the technological transformation of nature (52-53). This is Szerszynski's way of characterizing instrumental rationality, generally viewed as the hallmark of the modern world view, which he traces through a much longer historical context.

Within these broad parameters, two alternative views of nature emerged in the modern period. One has been the Romantic vision of nature as an Edenic paradise, free from human sin and imperfection. The other has been the vision of nature after the fall, a place of moral imperfection to be rectified through the application of techne. This latter view is most clearly associated with Baconian science. In this view, nature can be understood rationally, but this rational understanding is itself inscribed in a larger framework of value in which nature can be perfected according to the moral calculus of human rationality. Szerszynski writes (2005: 55):

From Francis Bacon's Advancement of Learning ([1605] 1960) onwards, technology became conceived as a project to liberate humankind from finitude and necessity, allowing it to share in the unconditionedness of a deity understood in increasingly sublime terms (Noble 1999; Song 2003).

Bacon viewed science and the concomitant technological perfection of nature as necessary not in and of itself but because of a moral obligation to bring about an Edenic perfection. The view that science and technology are meant to give humans dominion over nature has since then become a deep-seated view of the relationship between humans technology and nature (Smedes 2009).

So far this account of the modern worldview parallels quite closely the thesis advocated by Lynn White (1960). However, Szerszynski is quite sure that these theological developments do not in fact amount to what Weber termed the secularization or disenchantment of nature (Entzauberung); to the contrary he is quite clear that the ultimate absence of God from the modern view of nature does not strip it bare of meaning but rather enables 
the the natural world to be imbued once again with a new and vital profusion of sacral meanings. The disenchantment of nature is an illusion that takes the appearance of reality only from a certain perspective:

The illusion that the sacred has disappeared is arguably a feature of all historical transitions from one form of the sacred to the next in a given society. Each transition can seem like the eclipse of the sacred in the terms in which it was organized in the closing epoch; from a larger historical perspective, however, it can be seen as the emergence of a new sacral ordering (Szerszynski 2005: 26).

The continued attribution of sacred qualities to the "natural" world is evident in the current debates surrounding biotechnology, and in particular the notion of "playing God" in the genetic modification of plants and animals.

\section{Playing God}

In considering the modern concept of the "environment," Szerszynski notes that the nature has been wrested out of the hands of a unitary science and become the contested battleground of multiple political voices (2005: 150). Among those voices is one that decries the impact of human beings upon nature, as though these were two distinct beings. Taede Smedes writes (2009: 41):

For many people, the influence of humanity in and upon nature is something that should be kept to a minimum as much as possible. Human influence on nature, especially involving technology, is somehow considered to be "unnatural." The way many people speak about the relationship between humans and nature is as if humans are not part of nature, are somehow above or over against nature, so that human actions that affect nature are "interventions."

Such a view of nature, common but not hegemonic among the competing voices of the postmodern situation, clearly imbues nature with sacral meanings and views humans as being fundamentally different from nature precisely because of their "unnatural" capacity to "interfere" in nature by means of "technology." Such a vision regards nature as possessing a primal sacred quality. That is, it is to be clearly distinguished from the profane 
realm of humanity whose self-interested, even sinful motivations are to be mistrusted.

In essence, this view appears to be the diametric opposite of the Baconian view that humans have a moral responsibility to improve nature. The more radical point to note, however, is that these views share precisely the same overarching framework for considering humans and "nature." The view that we should not "interfere" with "nature" is identical with the Baconian view inasmuch as it regards humans as occupying some distinct position over and above "nature" and posits an absolute distinction between them. In both views humans are alienated from nature, and reify nature as some distinct ontological category. The modern environmentalist view differs from the Baconian scientist in locating the sacred not in the human technological project to redeem nature back into some prelapsarian paradise, but rather in regarding nature as already imbued with those pristine, Edenic qualities.

Thus when biotech companies argue that genetic modification can help developing nations feed themselves more efficiently or bring about cures for cancer, and when anti-GMO groups argue against human modifications of genes, they are both inhabiting the same modern Western worldview in which technology is seen as the means to mediate (and thereby distinguish) humans from nature. Both presuppose a radical discontinuity between the human world and the natural world. They differ in terms of the moral value of that discontinuity.

This implicitly theological discourse about nature and technology becomes explicit when people describe genetic modification as "playing God." The meaning of this term can best be understood when one takes into account the fact that it is invoked frequently in the context of genetic modification and in particular in the context of the creation of transgenic organisms. Two points need to be made. The first is that the concept of God that is invoked in the term 'playing God' is God as creator. This vision of God is fully developed in the Jewish-Christian-Islamic religious system, which regards God as unique by virtue of his status as creator. This absolute disjunction between creator and creature is seen as an inviolable dividing line. In Islamic theology the arrogation of divine attributes by anything other than God is considered to be shirk, a theological crime bound up with notions of hubris and disobedience. But why in particular does genetic modification warrant the term "playing God"? After all, the technological 
manipulation of nature is nothing new. It has been going on for years through well-established principles of animal husbandry such as hybridization. The answer to this question lies in the fact that genes are not considered to be attributes of nature that are being modified or manipulated by human artifice. Rather genes are considered in the popular imagination to be essential determinators of biological life, and relatively little emphasis is given to the fact that environmental factors are key to how genes are expressed.

This special status given to genetic modification can be seen in particular in the work of Francis Collins, the director of the Human Genome Project, who famously described the project as "the most important and the most significant project that humankind has ever mounted" (quoted in Noble 1997: 191) and then went on to write a recent book on this subject, entitled The Language of God (Collins 2006). It is perhaps no surprise that Francis Collins is himself an evangelical Christian, and a champion of the use of theological language to describe genetic research. While he may be comfortable with his role as divine co-creator, many popular critics of genetic modifications are not-but for precisely the same reasons. They both hold the view that genes are to do with the fundamental laws of life and therefore genetic modification is not simply one more incremental advance, but in fact a wholly revolutionary way of doing science.

In all this debate one thing is clear. Both advocates and detractors of genetic research share the same theological worldview in which genetic life is viewed as the product of a unique agency that is ontologically distinct from ordinary human creativity. Ellen ter Gast summarizes Ronald Dworkins's view of this as follows (2006: 4):

Everybody intuitively feels there is a dividing line between what we are or nature is, whether this is the work of God or a blind process, and what we create when we change what is given by nature. This distinction, argues Dworkin, is the back bone of our morality. Biotechnology, like no other technology, challenges this distinction.

This quintessential view of the absolute disjunction between man and nature ought to have been mitigated by Darwin's theory of evolution. Taede Smedes (2009) quotes Michael Ruse:

If you take Darwin seriously-accepting evolution through natural selection and not merely some Spencerian bastard version of evolution-then the spe- 
cial status of Homo sapiens is gone forever. Any powers we have are no more than those brought through the crucible of the evolutionary struggle and consequent reproductive success. It is true that, as a species, we are unique, with our own special combination of powers and abilities. But then, so also is Drosophila melanogaster (a species of fruit-fly) (Ruse 1986: 104).

Darwin's view of nature has not fully taken a hold of Western cultural consciousness not simply because it challenges our intuitive psychology, as Dworkin suggests, but because it also challenges our culturally encoded theological presuppositions about the nature of nature. Smedes's goal is to challenge the absolute distinction between humans and other animals. $\mathrm{He}$ notes Kenneth Oakley's (1972: 1) observation that "man may be distinguished as the tool-making primate" and that "employment of tools appears to be his chief biological characteristic" and then goes on to demolish this view with many examples of the use of technology by other animals. The difference lies not in technology per se but in the vastly superior cognitive capacities of the human brain, capacities that are increasingly seen by neuroscientists as products of the embodied human's engagement with the environment.

Why then is there such cultural resistance to the blurring of the technosphere and the biosphere if we are, from the beginning, biotech beings? We can investigate this by examining the language and imagery surrounding transgenic animals.

One famous example of such imagery can be seen in the work of various artists who have worked on depicting transgenic mice. Ellen ter Gast describes the work of Bryan Crockett, a sculptor famous for his six-foot tall sculpture Ecce Homo the OncoMouse, marble depiction of the transgenic mouse patented and trademarked by Harvard University. Crockett describes this sculpture in explicitly theological terms.

Science has taken over the authority that religion once held. In this body of work, I am exploring the sacredness of the flesh and soul in a time when we have acquired the knowledge and tools to play God (Crockett 2001).

These terms become explicitly Christian when he goes on to describe his sculpture as a Christ-figure.

That is why I have chosen to reinterpret the ultimate figure of salvation, Christ, through the ultimate actor of contemporary science, the Oncomouse. 
This sculpture is intended to be a monument to the test object of modern science, human kind's symbolic and literal stand-in personified. This humanscale, fleshy mouse, sculpted with the pathos of classical sculpture, stands in a gesture reminiscent of Christ revealing his wounds (Crockett 2001).

There is an element to the interpretation of Crockett's work that ter Gast does not mention, and that is the close identification of many religious figures with animals of various sorts in religious mythologies. Not least in the Jesus story is the adoration by the magi seen in Christmas cribs in churches across the world where the innocence of Jesus is symbolized by his proximity to all manner of animals. This theme is of course inverted in the story of the crucifixion in which Jesus is depicted himself as the innocent lamb, slaughtered on behalf of guilty men. Jesus's transgression of the divine-human boundary is fused together in Christian imagery with his characterization as sacrifical lamb. As such the animal, human and divine realms are interpenetrated.

Such an interpenetration is also evident in Crockett's depiction of the OncoMouse as a Christ figure. According to Ellen ter Gast, Crockett's work clearly symbolizes the way in which technology has become part and parcel of our modern belief system, a system that builds on Christian motifs, albeit whose theological DNA has been itself "genetically modified." She concludes that the explicit use of theological language by advocates and detractors of genetic engineering alike is not a matter of rhetoric or strategizing but something altogether deeper (see Nelkin 2004). Like David Noble (1997) she sees technology as a contemporary religious form. Or as David Nye puts it, technology has become a new form of the sublime, awesome and fascinating, enchanting and enthralling, betokening either salvific or demonic power, depending on one's perspective (Nye 1994).

So far I have tried to have depict the ways in which debate about biotechnology research is shaped by broad theological and cultural factors, factors that are perhaps rooted in a universal intuitive psychology, but which receive expression in particular cultural forms.

But what about the status of genetic modification in cultural systems which do not have their roots in the West Asian Jewish-Christian-Islamic belief system? On the one hand the development of modern science and technology is thoroughly implicated in the history of Western religions and theologies, and thus wherever it takes place across the globe, it brings with it the vocabulary and presuppositions that are in part derived from 
the Western enlightenment period. On the other hand as science and technology become rooted in non-Western cultures, future developments may not always be constrained or envisioned within the modern Western cultural imagination.

\section{Chinese Cultural Factors}

I want in the final part of my paper to suggest some ways in which Chinese views of nature, animals and technology might entail a different take on science and technology issues that are contentious in the West precisely because of the religiously-derived vocabulary in which they are discussed. These suggestions are, if you like, hypotheses that I that could be tested through social science research. Here they are listed, for what they are worth, as hypotheses.

There has never been a strong concept of a singular creator God in Chinese religion and culture. The alternative concept has been that of humans "forming one body with heaven and earth." Generally this has involved a more monistic metaphysical picture in which humans work with creative spiritual forces symbolized by heaven and biophysical nature symbolized by earth to promote the continuing evolution of the way. In this regard humans are already cocreators. There is no absolute disjunction between the heavenly realm and the earthly realm, between humans and God, or between humans and nature. In this regard traditional Chinese metaphysics seems more closely allied with Darwinian evolutionary theory than the atomic materialism of the Western enlightenment. My hypothesis from this is that there should be little impetus to describe genetic modification positively as "decoding the language of God" or negatively as "playing God."

Nature is always understood as being in process. Nature is self-so, automatic, following its own immanent teleological processes. This has produced a view of nature and naturalness that, from a Western perspective, is ambiguous. On the one hand it seems to indicate that nature should be respected, that it has its own purposes which are distinct from human purposes. On the other hand it goes against the notion that the human role is to preserve nature in some immaculate pristine condition, because nature (including humans) is always in flux, always responding in an organic way with the other processes of the system. The system as a whole 
takes priority over the individual elements. My hypothesis is that while there might be a drive to preserve the iconic significance of China's magnificent landscapes and to rid them of pollution, such a preservation would not likely the form of wilderness protection areas, at least not from a traditional Chinese perspective. Landscapes must always function as habitats for humans, animals and other species all of which are "part of nature," all of which should strive to coexist in some harmonious and creative way. Development is inevitable; the goal should be harmonious coexistence.

While there is strong tradition of incorporating mythical beasts in to China's religious and cultural imaginary, its religious traditions do not as a whole rely heavily on real animals as religious symbols within their mythological narratives. Rather, religious imagery in Chinese traditions is more obviously construed analogically and cosmologically, in terms of the modes of relationship between humans and the Way. These analogies are frequently mediated by the natural world, but most frequently in terms of mountains, stars, plants, that is to say, the non-animal world. One reason for this is that animals share all too obviously the same kind of natures as human beings. If in Daoism the goal is some kind of transcendent immortality, animals do not seem to be particularly good symbols for this. Rivers, streams, mountains and forests on the other hand, are examples of living nature that clearly transcend the ordinary human experience of temporal finitude. Whereas lambs might be symbols of immortality in Christianity they are so not as the result of their biological nature but because of their symbolism within the sedimented layers of the Christian mythological imagination. Thus although animals do play a role in the Daoist and Buddhist imagination in China, they are not fraught with the same degree of mythological significance as one finds in Biblical narratives. My hypothesis from this is that there should be little impetus to preserve specific species, or to regard specific animals as totems of ecological devastation as a whole, in the way that seals or whales hold a special place in the public consciousness in the West. The closest that we get to this in China are pandas who are seen as national icons, and are thus a special case. On the other hand, successful environmentalism in China will more likely be framed in terms of the continuing harmonious development of broader social-economiccultural ecosystems. There will be no iconic battles to save the whale, and there will be less revulsion at the concept of transgenic animals. 
In conclusion, the Chinese religious-cultural context is probably going to be more favourable to biotechnology research than the Western context because it is rooted in a different conception of nature, humanity and the sacred. The status of humans as cocreators is already explicit in the Chinese imaginary. The view of nature as evolving alchemical process, rather than essentialized substance, lends itself to more widespread public acceptance of transgenic organisms. Finally, many environmentalists have regarded Chinese tradition as a source of alternative wisdom concerning the human relationship with nature. It is true that Chinese cultural and religious ideas are radically different than those that have developed in the West. I believe, however, that they do not support the position taken by many environmentalists and opposers of biotechnology research that nature is somehow sacred and therefore to be kept distinct from human interference.

\section{List of Works Cited}

Crockett, David B. 2001. http://www.decordova.org/decordova/exhibit/2001/terrors/crockett. htm.

ter Gast, Ellen. 2006. "Ecce homo, the transgenic mouse and the Christ metaphor." Paper presented at the conference on Religion, Science, and Public Concern: Discourses on Ethics, Ecology, and Genomics, Leiden University, Netherlands, October 26-27, 2006.

Nelkin, Dorothy. 2004. "God Talk: confusion between science and religion." Science, Technology and Human Values 29.2: 139-152.

Noble, David F. 1997. The Religion of Technology: The Divinity of Man and the Spirit of Invention. New York: Random House.

Nye, David E. 1994. American Technological Sublime. Cambridge, MA: MIT Press.

Oakley, Kenneth P. 1972. Man the Toolmaker. Sixth Edition. London: The British Museum (Natural History).

Ruse, M. 1986. Taking Darwin Seriously: A Naturalistic Approach to Philosophy. Oxford: Blackwell.

Smedes, Taede A. 2009. "Technology and What It Means to Be Human.” Pp. 41-54 in Willem B. Drees, ed., Technology, Trust, and Religion: Roles of Religions in Controversies on Ecology and the Modification of Life. Leiden: Leiden University Press, 2009.

Szerszynski, Bronislaw. 2005. Nature, Technology and the Sacred. Oxford: Blackwell. 